\title{
Reconsideration of the Huangpu Military Academy and the Huangpu Spirit
}

\author{
Zhimin Lei ${ }^{1}$ \\ ${ }^{1}$ College of Politics, Sichuan Agricultural University, Chengdu, China \\ Correspondence: Zhimin Lei, College of Politics, Sichuan Agricultural University, Chengdu 611130, China. \\ E-mail: zhiminlei2007@163.com
}

Received: March 2, 2013 Accepted: March 13, 2013 Online Published: May 30, 2013

doi:10.5539/jpl.v6n2p163 URL: http://dx.doi.org/10.5539/jpl.v6n2p163

\begin{abstract}
Huangpu Military Academy is an outcome of cooperation between the two parties of the Kuomintang and the Communist Party of China and the spirit of Huangpu is an achievement of common cultivation of the two parties. In the new situation, a review of the establishment of Huangpu Military Academy and carrying forward the spirit of Huangpu is of important realistic significance to promote rejuvenation of the Chinese nation.
\end{abstract}

Keywords: Huangpu Military Academy, Huangpu spirit, rejuvenation of the Chinese nation

Huangpu Military Academy was established during the first Kuomintang-Communist cooperation period. At the times of the first revolutionary civil war, as Huangpu Military Academy was the first to break down the limitations between different parties and doctrines, to dedicate to common efforts by the two parties of the Kuomintang and the Communist Party, to realize the struggling target of "overthrowing big powers, eliminating warlord" and unifying the great China, Liao Chung-k'ai wrote in his own handwriting and spoke highly of this military and political school initiated by the two parties of the Kuomintang and the Communist Party, commending it as "blood of the revolutionary martyrs and flower of the doctrines." (Manuscript of the History of the Central Military Academy)

A review of the history of establishment of Huangpu Military Academy and the Huangpu spirit, without doubt, has realistic significance to promote solidarity of the compatriots on both sides of the Taiwan Straits and realize unification of the nation and the great dream of rejuvenation of the Chinese nation.

\section{The History Process of Building Huangpu Military Academy by the Two Parties of the Kuomintang and the Communist Party of China and Its Characteristics}

Establishment of the Huangpu Military Academy contributed to the common efforts by the two parties of the Kuomintang and the Communist Party of China. Sun Yat-sen led anti-Qing revolutionary struggles for several times and launched a series of military activities. After the Republic of China was set up, he resorted to the Southern Warlord to oppose the Northern Warlords, but finally he failed to establish real revolutionary armed forces and he was defeated each time. Sun Yat-sen concluded in this way, "Our revolution only has struggling of the revolutionary party, and there is no struggling of the revolutionary army. As there is no struggling of the revolutionary army, generally, any common bureaucratic warlord may keep the Republic of China under control, so our revolution is not able to succeed totally." (Sun, p. 850) And he had made great efforts to search for organization of the revolutionary army.

The October Revolution brought new enlightenment and hope to Sun Yat-sen. The Huangpu Military Academy was set up under the circumstance that Sun Yat-sen yearned for achievement of "the October Revolution" followed the example of the Soviet Russia by taking the Soviet Union as a model, made cooperation between the Communist Party of China and the Kuomintang and set up the revolutionary army to save China in peril. Ma Lin, the representative of the Communist International, had an interview with Sun Yat-sen, which was exactly reflection of realization of the above thought.

The two parties of the Kuomintang and the Communist Party had made a lot of efforts in order to promote interview of Sun Yat-sen and Ma Lin in Guilin. According to Ma Lin (Yi, 1923), he had the opportunity to meet with Sun Yat-sen through introduction of the Kuomintang member Zhang Ji and with invitation from the Kuomintang. The Communist Party of China sent Zhang Tailei to make a special trip in the company of Ma Lin 
to go to Guilin and the Zhang Tailei served as the translator and guide. He also accompanied Ma Lin to meet with all classes of people in the Chinese society. All this provided important information and help for Ma Lin to put forward relative strategies for the first Kuomintang-Communist cooperation in the future.

As a result of divergence of the two parties of the Kuomintang and the Communist Party of China, progress of the implementation of specific measures in the interview between Ma Lin and Sun Yat-sen in Guilin was sluggish. In 1923, the Communist Party of China held the "Third National Congress of the Communist Party of China" in Guangzhou. With the help of the Communist International, the Communist Party of China sized up the situation and decided to join in the Kuomintang with a personal identity as a Communist Party member and cooperated with the Kuomintang. In October in the same year, Li Dazhao held the position as one of the five committee members in the reorganized Kuomintang. (Guangzhou Republic Daily, October 19, 1923) The Communist Party of China had sincerely mentioned that Mr. Sun Yat-sen "just sometimes turned to other powerful forces' emotion towards him who were his good friends yesterday and may turn suddenly hostile today and maybe will become his enemy tomorrow." The armed forces in the future had to set up an army in accordance with the Red Army of the Soviet Union, as "a strong red army could organize successfully just because it has real revolutionary spirit,... so red army is a really revolutionary army, and, at any time, it prepares to sacrifice for protection of the red flay of the social revolution". (Xiang Dao Weekly, 1922) Sun Yat-sen accepted the suggestion and decided to re-organize the Kuomintang to cooperate with the Communist Party of China in the "First Conference" of the Kuomintang. Meanwhile, he also initiated the officer academy and organized revolutionary forces. It was exactly under the common efforts of the Kuomintang and the Communist Party of China that from meeting of Sun Yat-sen and Ma Lin to establishment of the Huangpu Military Academy gathered wisdom and courage of the two parties of the Kuomintang and the Communist Party of China and also members of the two parties.

The cultivation tenet and the system construction of the Huangpu Military Academy gathered the common efforts by the two parties of the Kuomintang and the Communist Party of China. Firstly, the two parties constituted "Sun Yixian Doctor Delegation" which was constituted by the four members of the two parties --Chiang Kai-shek, Zhang Tailei, Shen Dingyi and Wang Dengyun who visited, one after another, all arms of the services and all facilities in Soviet Union. They also sent consultants to have discussions on establishment of armies according to the system of the red army and on how to launch Chinese revolutionary and military struggles and finally attained achievements. Secondly, in terms of specific administrative policies, with the concerted efforts of the members of the two parties of the Communist Party of China and the Kuomintang and with the help of the consultants from the Soviet Union, Huangpu Military Academy was the first new type of military academy in the Chinese history. For instance, it had a definite cultivation target, a complete organizational institution, educational plan and rules and regulations. The cultivation target of the academy was to cultivate military cadres who could not only command a combat but also could guide political work. The Huangpu Military Academy simulated the Soviet Union Red Army system to organize a party army system under the leadership of the party and became a sample of Chinese revolutionary officer academy. In the Huangpu Military Academy, the members of the Communist Party and the League members as well as progressive young people played a role of backbone and the Communist Party members headed by Zhou Enlai set up "Huangpu Special Branch of the Communist Party of China" as the core of leadership to conduct activities in the military school. They also organized "Mars Institute" and initiated "Chinese Army" to publicize the revolutionary ideas and enhance the political level and class consciousness of students in the military academy.

Excellent Combination of excellent instructors and excellent students sharpened intrepid struggling force of the Huangpu Military Academy. At that time, although Sun Yat-sen set up Guangdong generalissimo office in Guangzhou, its revolutionary power was only confined to the area of Guangzhou and even the generalissimo ordered anyone should not "go out of the cement factory in Guangdong (the location where the generalissimo office was located)". (Yu Rong, 1927) After the "First Conference" of the Kuomintang, both the members of the Kuomintang and the members of the Communist Party of China were together responsible for the recruitment of new students for the Huangpu Military Academy. For example, Mao Zedong held the position as the executive committee member of the Division of Enforcement of Kuomintang in Shanghai and was also responsible for the job of reexamination of new students sent by the Yangtze River Basin and all areas in the North China and transmission of these new students to Guangzhou. (Guo Yiyu) Yu Youren recommended the Communist Party member Yan Kuiyao and the Kuomintang member Hu Zongnan to go to the military academy to resiter for examination. The Kuomintang member Deng Wenyi admitted that, he was recommended by the Communist Party. There were a lot of examples in such that the Communist Party members recommended Kuomintang members to register for examination and the Kuomintang members recommended the Communist Party 
members to register for examination. At that time, the Communist Party member Zhang Shenfu moved from Beijing to Guangzhou under the recommendation of Li Dazhao and participated in the examination for new students. The Kuomintang member He Zhonghan was recruited by Zhang Shenfu. The Kuomintang and the Communist Party of China made selfless cooperation in cultivating revolutionary military soldiers in order to achieve a common objective --- overthrowing the warlords and eliminating big powers. The two parties of the Kuomintang and the Communist Party of China did their level best in sincere cooperation in sending excellent teachers to the Huangpu Military Academy. The Kuomintang members, Mr. Sun Yat-sen holding the position of the premier of the academy, Liao Chung-k'ai, Chiang Kai-shek, Wang Ching-Wei, Hu Hanmin, Cheng Lifu and Zhang Zhizhong and the important trusted followers of Sun Yat-sen as well as the subsequent important Kuomintang members held positions successively in the academy. Meanwhile, they also served with a key position in the revolutionary government. The Communist Party members Zhou Enlai, Yun Daiying, Nieh Jung-chen, Ye Jianying and Xiao Chunv etc. held the positions of leaders and instructors in the academy and made important contributions to the education and teaching of the academy. The joint efforts of the Kuomintang and the Communist Party members and the fact Zhou Enlai and others set up the political education and political working system in the academy according to the experience with which Lenin set up the red army not only made the military academy distinguished from all old military schools in the past in China and sharpened the intrepid struggling forces, but also accumulated precious experiences for construction of the political work in the national revolutionary army later and played an important role in transforming the old army and establishing the revolutionary army.

After establishment of the Huangpu Military Academy, from February to May 1924, there were three thousand young people from Shanghai, Zhejiang and Guangzhou who registered for the academy. The academy altogether held seven terms of instruction from its establishment until 1927 when Chiang Kai-shek launched the "July 15th Counter-revolutionary Coupd'etat". There were altogether (223) 449 students in the second term (from August 1924 to January 1925), 1233 students in the third term (from 1925 to January 1926), 2654 students in the fourth term (from March 1926 to October 1926) and 2600 students in the fifth term (from December 1926 to April 1927). Through the training within the five terms, there were almost seven thousand students who graduated from this academy which cultivated an important military power and a batch of excellent military cadres for the revolution. And the sixth term and the seventh term were held continuously by Chiang Kai-shek respectively in Guangzhou and Nanjing. The military forces with the backbone of students from the Huangpu Military Academy became a powerful revolutionary and military force in Guangdong revolutionary government pacifying the rebellion from the Merchants Group, in the first and second expedition east and in the several wars whittling the power of the Diangui warlords Yang Ximin and Liu Zhenhuan. In the Northern Expedition, the national revolutionary army with the backbone of student soldiers from the Huangpu Military Academy played an enormous role. It can be said that it is the powerful reflection of the new type of revolutionary army with integration of military and politics constructed by the Huangpu Military Academy that overthrew the ruling of northern warlords in the Northern Expedition from the time when the army was commanded to troop from south to north and to the time when the army struggled from the Pearl River to the Yangtze River Basin.

\section{Reconsideration of the Realistic Significance of Carrying forward the Huangpu Spirit}

Huangpu Military Academy is the first military academy with modern significance that was founded by Sun Yat-sen and has significant historical influences upon cooperation between the two parties of the Kuomintang and the Communist Party of China. Huangpu Military Academy has become a history, but the spirit of Huangpu still flickers brilliance of the times. Under the new circumstance, a review of the establishment process of Huangpu Military Academy and carrying forward the Huangpu spirit are of important realistic significance to promote rejuvenation of the Chinese nation.

The core significance of carrying forward Huangpu spirit is to inherit excellent historical traditions, push forward the national spirit of compatriots from both sides of the Taiwan Straits to together carry forward the patriotism and practically facilitate realization of the great cause of reunification of the nation.

"Emergence of a thought isn't without foundation and formation of a spirit also has its conditions and process. The same is true with Huangpu spirit". ( $\mathrm{Li}, 2006)$ Then, what is Huangpu spirit? The one who put forward this concept earlier is Guo Huaruo, a student from Huangpu Military Academy. According to him, specifically speaking, "Huangpu is based on the three major policies defined by the Prime Minister, namely, (1) alliance with Russia, (2) alliance with the Communist Party, and (3) upholding farmers and workers... Strict enforcement of the spirit of our three major policies in alliance with Russia, alliance with the Communist Party, and upholding farmers and workers is, so far, the Huangpu spirit" (An, 1926) The three major policies of alliance with Russia, alliance with the Communist Party, and upholding farmers and workers was put forward by Sun Yat-sen. And the 
new three principles of the people centered with the three major policies were the political foundation for cooperation between the Kuomintang and the Communist Party of China for the first time. The three major policies put forward by Sun Yat-sen and establishment of Huangpu Military Academy was to resolve the social issues of rampage of warlords and manipulation by big powers. Just as Sun Yat-sen said, the unique hope to start this military academy here was to create revolutionary army and to secure peril of the Chinese nation. Sun Yat-sen held highly the big flag of the patriotic revolution until the end of his life and branded with a deep mark on the Huangpu Military Academy.

Hence, it can be seen that the national spirit centered with patriotism is the quintessence of Huangpu spirit. "National spirit is the spiritual pillar for a nation to survive and develop. Throughout the five thousand years of development history, the Chinese nation has formed the great national spirit with characteristics of the times and with patriotism being the core, namely, unity and solidarity, love of peace, industriousness and courageousness and self-motivation". (Yu, 2006)

It is in the darkest times throughout the Chinese history and under the circumstance in which warlords fought against each other in confusion of separation and the masses had no means to live that the Huangpu Military Academy was established after twists and turns and constantly overcoming all kinds of difficulties. "The Huangpu spirit with the core of 'patriotism and revolution' is exactly a precious spiritual wealth created by Huangpu Military Academy at that time in the great revolutionary struggle" (Yu, 2006)

The Huangpu spirit centered with patriotism had different manifestations during different periods. During the period of the Crusades and the Northern Expedition, the two parties of the Kuomintang and the Communist Party of China held highly the flags of "patriotism" and "revolution" to "overthrow big powers and get rid of warlords" and gained victory of the Crusades and the Northern Expedition during the great revolutionary period. During the anti-Japanese war, for independence and liberation of the nation, the two parties of the Kuomintang and the Communist Party of China held highly the big flag of Huangpu to expel the Japanese imperialism out of China and gained victory of the anti-Japanese war. During the times of war, Huangpu spirit was specifically manifested as the spirit of the officers and soldiers of patriotism, solidarity, discipline obedience and sacrifice.

Huangpu Military Academy is an outcome of the cooperation between the two parties of the Kuomintang and the Communist Party of China and Huangpu spirit is also the achievement of cultivation of the two parties. As a result of historical reasons, today both of the sides of the Taiwan Straits is still at a condition of separation and national revival and national reunification is the great mission that history endows with us. Realization of national reunification and national revival is an ideal of the revolutionary predecessors of Sun Yat-sen and others. Seventy-five years ago, Sun Yat-sen said that reunification was the hope of all national citizens and if the nation could be reunified, all the people of the nation would feel happy; otherwise, all of them would get hurt.

Thus, we carry forward Huangpu spirit today is to exceed feelings of gratitude or resentment in the history and not to haggle over gains and losses in the past, to disregard the previous enmity and face up with the daily changing situation in the world and the Asia-Pacific area with one heart and one mind, and to cooperate by the two parties of the Kuomintang and the Communist Party of China to safeguard the fundamental interest of the nation and the sovereign rights of the nation and to protect completeness and independence of the territorial sovereignty of the nation.

Carrying forward the Huangpu spirit is to strengthen communication between the political parties of both of the sides of the Taiwan Straits, and especially communication between the people of both of the sides, not only to expand economic and cultural communication, but also to further consolidate mutual political confidence, to oppose any separation behavior and push forward national revival and national reunification under the blueprint of "one nation, two systems".

It is necessary to carry forward Huangpu spirit as it is a powerful motive for both of the sides of the Taiwan Straits to revitalize the Chinese nation. It is based on the lofty ideal of "reunifying the motherland and revitalizing the Chinese nation" that Sun Yat-sen initiated Huangpu Military Academy, in the hope of building a unified, wealthy, free and democratic and new China.

As the great cause of revival and reunification of the Chinese nation, it is not finally achieved by a single political party. Instead, it requires each social class and political party to take Huangpu spirit as the model and to cooperate and unify with the centripetal force of the nation to really achieve revival of the Chinese nation and to stand on the top of the world. The experience of the history tells us that harmony means development and cooperation means national prosperity, struggling means damage and separation means national decline. As a matter of fact, cooperation of both of the sides of the Taiwan Straits hand in hand to revitalize the Chinese nation is the essential reflection of Huangpu spirit and is the historical mission that each member of the Chinese nation 
ought to bear in mind and put into practice.

\section{References}

An, T. C. (1926, September 23). What Is Huangpu Spirit? Huangpu Daily.

Guangzhou Republic Daily. (1923, October 19).

Guo, Y. Y. (n. d.). Manuscript of the Fragment Memory about the Huangpu Military Academy.

Li, Z. C. (2006). Huangpu, (3).

Manuscript of the History of the Central Military Academy, frontispiece.

Sun, Y. S. (n. d.). Selected Works of Sun Yat-sen (Vol. 2, p. 850).

Xiang Dao Weekly. (1922, November, No. 9).

Yi, L. S. (n. d.). Record of the Talk with Hendricus Sneevliet. Materials Related to Visit of Ma Lin in China.

Yu, J. Q. (2006). Splendid History Annals of the Contributions of Huangpu Military Academy, Huangpu Spirit Shining Forever. Journal of Shaanxi Radio \& TV University, (1).

Yu, R. (1927). Developing Huangpu Spirit. Special Edition for Discussing Chiang Kai-shek, Brach campus in Wuhan, April 23.

\section{Copyrights}

Copyright for this article is retained by the author(s), with first publication rights granted to the journal.

This is an open-access article distributed under the terms and conditions of the Creative Commons Attribution license (http://creativecommons.org/licenses/by/3.0/). 